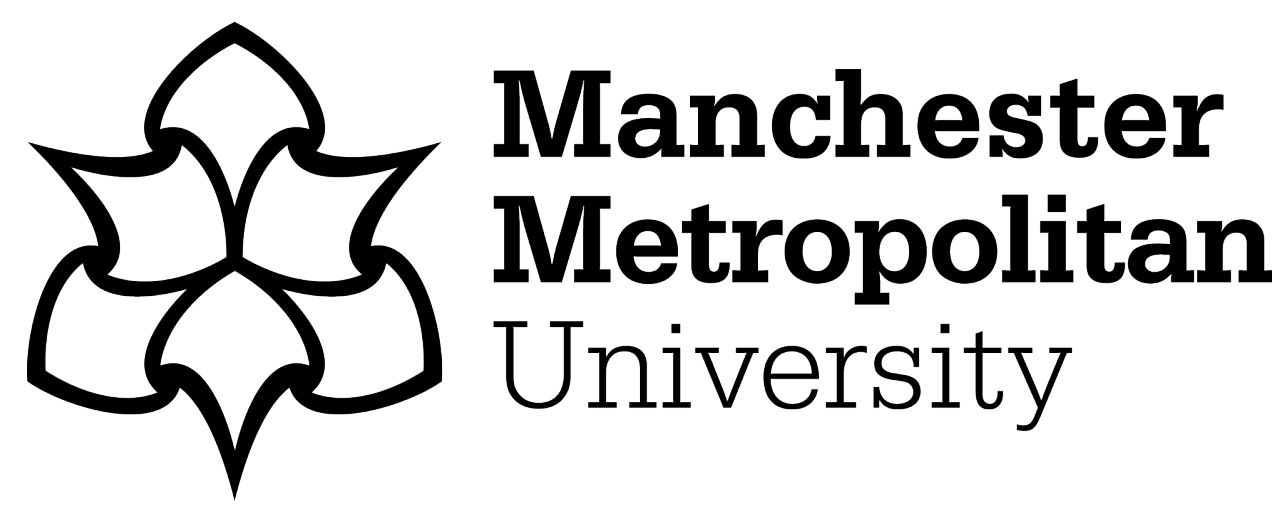

Aarons, Toby, Bradburn, Steven, Robinson, Andrew, Payton, Antony, Pendleton, Neil and Murgatroyd, Chris ORCID logoORCID: https://orcid.org/00000002-6885-7794 (2019) Dysregulation of BDNF in Prefrontal Cortex in Alzheimer's Disease. Journal of Alzheimer's Disease, 69 (4). pp. 1089-1097. ISSN 1387-2877

Downloaded from: https://e-space.mmu.ac.uk/623014/

Version: Accepted Version

Publisher: IOS Press

DOI: https://doi.org/10.3233/jad-190049

Please cite the published version 


\section{Dysregulation of BDNF in prefrontal cortex of Alzheimer's disease}

Toby Aarons ${ }^{1}$, Steven Bradburn ${ }^{1}$, Andrew Robinson ${ }^{2}$, Antony Payton ${ }^{3}$, Neil Pendleton ${ }^{2}$, Chris Murgatroyd ${ }^{1 *}$

${ }^{1}$ Bioscience Research Centre, Manchester Metropolitan University, Manchester, United Kingdom

${ }^{2}$ Faculty of Biology, Medicine and Health, School of Biological Sciences, Division of Neuroscience \& Experimental Psychology, University of Manchester, Salford Royal Hospital, Salford, M6 8HD, UK.

${ }^{3}$ Division of Informatics, Imaging \& Data Sciences, School of Health Sciences, The University of Manchester

* Dr Chris Murgatroyd, Bioscience Research Centre, Manchester Metropolitan University, Chester Street, Manchester, United Kingdom, M1 5GD. Tel: (+44)1612471212. E-mail:

c.murgatroyd@mmu.ac.uk.

Running title: $B D N F$ regulation in ageing and Alzheimer's disease 


\section{Abstract}

Background: Brain-derived neurotrophic factor (BDNF) is essential for neurogenesis and has been implicated in Alzheimer's disease (AD). However, few studies have investigated together the epigenetic transcriptional and translational regulation of this peptide in the brain in relation to AD.

Objective: To investigate mechanisms underlying for how $B D N F$ is possibly dysregulated in the brain in relation to ageing and $A D$ neuropathology.

Methods: Prefrontal cortex tissues were acquired from the Manchester Brain Bank ( $N=67)$. BDNF exon I, and exon IV containing transcripts and total long 3' transcript gene expression were determined by quantitative PCR. Bisulfite pyrosequencing was used to quantify DNA methylation within promoters I and IV. Protein concentrations were quantified via an enzyme linked immunosorbent assay (ELISA). Donors were previously genotyped for the rs6265 (Val/Met) polymorphism.

Results: BDNF exon IV and total long $3^{\prime}$ isoform gene expression levels negatively associated with donor's age at death $(I V: r=-0.291, P=0.020 ;$ total: $r=-0.354, P=0.004)$. Expression of BDNF exon IV containing isoform was significantly higher in Met-carriers of the rs6265 variant, compared to Valhomozygotes, when accounting for donor ages $(F=6.455, P=0.014)$. BDNF total long $3^{\prime}$ transcript expression was significantly lower in those with early AD neuropathology, compared to those without any neuropathology $(P=0.021)$. There were no associations between $B D N F$ promoter I and IV methylation or protein levels with ages, rs6265 genotype or AD neuropathology status.

Conclusion: Prefrontal cortex BDNF gene expression is associated with ageing, rs6265 carrier status and $A D$ neuropathology in a variant-specific manner. This dysregulation seems to be independent of DNA methylation influences at the $I$ and $I V$ promoters.

Key words: BDNF, DNA methylation, Alzheimer's disease, prefrontal cortex 


\section{Introduction}

Brain-derived neurotrophic factor (BDNF) is a neurotrophin that promotes neurogenesis, synaptic plasticity and long-term potentiation (LTP) in the CNS [1,2]. BDNF has been implicated in the 'age-bydisease hypothesis', in which BDNF expression is reduced in the ageing brain and a reduction in $B D N F$ expression has been associated with multiple neurological disorders [3].

Reductions in BDNF have been widely investigated as a mediator of age-associated decline in synaptic density and cognitive function [4], with a significant association between BDNF and cognitive ageing being observed [5-7]. However, the underlying mechanisms behind age-associated BDNF declines are not completely understood.

The human BDNF gene has a complex structure involving 9 promoters and 11 exons of which only the exon IX at the 5' end contains the coding sequence [8]. The untranslated 3' exons, through alternative splicing, lead to different transcripts that still contain common coding region at the $3^{\prime}$ end. Therefore, through the use of alternative promoters and splicing mechanisms, various different BDNF transcripts with alternative 5' untranslated regions (UTRs) can be generated that all code for the same BDNF protein. Finally, two alternative polyadenylated transcription stop sites in exon IX can lead to transcripts with either short or long 3' UTRs. A study has shown that while the short 3' UTR BDNF mRNA variant is restricted to the cell body in hippocampal neurons, the long $3^{\prime}$ UTR mRNAs are also observed in dendrites [9]. Together, in the human brain, all exons are expressed, but to different degrees in different brain structures (for review see [10]). It is thought that these different promoters allow BDNF to respond to a greater variety of stimuli that further result in the generation of different transcripts that are stable in multiple intracellular environments [8]. As BDNF promoters mediate differential BDNF isoform expression in various parts of the brain, it is thought that changes to their activity could affect cellular and behavioural phenotypes [11]. Epigenetic mechanisms, predominantly promoter methylation that generally serves to silence gene expression, have been shown to regulate BDNF expression [12]. BDNF promoter IV is one of the most widely investigated promoters in the contest of DNA methylation changes associated with alterations in BDNF expression: For example McKinney et al. [3] found in the orbital frontal cortex that DNA methyation at promoters I, II, and IV were increased in older people and negatively correlated with BDNF expression. Keller et al. [13], for example found significant increases in DNA methylation at BDNF promoter IV in the Wernicke area from suicide subjects, when compared to controls, that correlated with lower mRNA levels for BDNF exon IV containing transcript. In the periphery, increased methylation at BDNF promoters I and IV have been found in blood DNA from 
patients with Mild Cognitive Impairment $(\mathrm{MCl})$ compared to controls and increased methylation at CpGs in promoter IV predicted conversion from MCI to AD [14]. Further studies in blood DNA have shown increased $B D N F$ methylation at promoter I in $A D$ cases compared to controls $[15,16]$ and increased peripheral BDNF promoter I and IV in amnestic $\mathrm{MCl}$ compared to controls that further predicted the conversion from $\mathrm{MCl}$ to $\mathrm{AD}$ [14]. Interestingly, the conversion from amnestic $\mathrm{MCl}$ to $A D$ depended upon an interaction of methylation with a non-synonymous single nucleotide polymorphism (SNP) in the BDNF gene, rs6265 [17]. However there are some conflicting reports not finding increased BDNF methylation in peripheral DNA in AD compared to controls $[15,18]$. Within the CNS, Rao and colleagues [19], studying groups of $10 \mathrm{AD}$ and 10 control prefrontal cortex samples, found significant decrease in total BDNF mRNA in the AD brain compared to control brains together with increased promoter DNA methylation. A reduction in prefrontal cortex BDNF expression in AD has also been found in a study by Buchman et al. [19] on 535 older participants. Li et al. [29] found a reduction in temporal cortex and frontal cortex in AD, but specifically in females. They further found that rs6265 associated with transcriptional regulation only in the female brains. Garzon et al. investigating individual BDNF variants found transcript specific decreases of BDNF in AD brains. Few studies have investigated together the epigenetic, genetic, transcriptional and translational regulation of this peptide in the brain in relation to $A D$.

The aim of this study was to investigate mechanisms underlying the dysregulation of $B D N F$ within the AD brains studying human prefrontal cortex tissue for BDNF protein levels, promoter-specific expression, promoter DNA methylation specifically at promoters for exons I and IV and the rs6265 genotype.

\section{Methods}

\section{Study population}

Fresh, frozen tissue was taken from superior frontal gyrus (Brodmann area 8). Samples were acquired from donors through the Manchester Brain Bank. Ethical approval was granted from the Manchester Brain Bank Committee. Donors were participants of a large prospective cognitive ageing cohort known as The University of Manchester Age and Cognitive Performance Research Cohort $[20,21]$ and included all those with brain material and available neuropathological data.

Stratification into Alzheimer's disease neuropathology groups were based on the National Institute on Aging-Alzheimer's Association guidelines [22]. Briefly, the amyloid beta (A $\beta$ ) plaque score (Thal), neurofibrillary tangle stage (Braak) and neuritic plaque score (CERAD) were used to create an " $A B C$ " 
score. Four groups were determined: Not, Low, Intermediate and High AD neuropathologic change. Those with high levels of $A \beta$ and neuritic plaques with low neurofibrillary tangle score were excluded (“ABC" score: A2-3, B0-1, C0-3), due to potential contributions by other co-morbidities.

\section{Gene expression analysis}

Brain tissue ( $30 \mathrm{mg}$ ) was extracted for RNA using TRIsure ${ }^{\mathrm{TM}}$ (Bioline, UK), quantified using the Nanodrop 2000c (Thermo Scientific, Wilmington, USA) and qualifies using the Agilent Bioanalyser. RIN values are given in Supplementary Table 1. The Tetro cDNA synthesis kit (Bioline, UK) was used to reverse transcribe total RNA $(2 \mu \mathrm{g})$, according to the manufacturer's protocol using random hexamers. Relative gene expression was analysed using qPCR with SensiFAST ${ }^{\mathrm{TM}}$ SYBR $^{\circledR}$ Lo-ROX kit (Bioline), in accordance with the manufacturer's protocol using primers for BDNF exon I containing transcript (F: CAGCATCTGTTGGGGAGACGA; R: GCCACCTTGTCCTCGGATGT), BDNF exon IV containing transcript (F: TGGGAGTTTTGGGGCCGAAG; R: TGGTCATCACTCTTCTCACCTGG), BDNF total long 3', (F: GGACCCTTCAGAGGTGGCTC; R: GTCGGCTTGAGTGTGGTCCT), ACTB (F: CATCCTCACCCTGAAGTACC; R: ATAGCAACGTACATGGCTGG) and GAPDH (F: CCGCATCTTCTTTTGCGTCG; R:

TGGAATTTGCCATGGGTGGA). qPCR was performed on a Stratagene Mx3000P qPCR system (Agilent) in duplicate. Relative gene expression, accounting for primer efficiencies and normalised to GAPDH and $A C T B$, were determined using the geometric averaging method described by Vandesompele and colleagues [23]. Those samples with gene expression levels were not detected $(\mathrm{Ct} \geq 40)$ were excluded from analyses.

\section{Genotyping}

DNA samples were extracted from peripheral blood samples, as described previously [24]. Genotyping for the G196A/Val ${ }^{66}$ Met (rs 6265) was performed using the Kompetitive Allele Specific PCR (KASP) assay (LGC Ltd) in reaction volumes of 10ul together with 5ng of DNA that was run on a Stratagene MX3000P qPCR machine (Agilent). Fluorescence values were read by the MXPro software to enable genotype calling.

\section{Protein quantification}

Brain tissue ( $100 \mathrm{mg}$ ) were lysed using RIPA buffer (Sigma) supplemented with 1x protease inhibitor cocktail and 0.1 M PMSF, as described previously [25]. Quantification of BDNF protein was performed using the Human/Mouse BDNF DuoSet ELISA (R\&D Systems). Protein levels were normalised to total protein levels in the assay ( $\mathrm{pg} / \mathrm{mg}$ of total protein).

\section{DNA methylation analysis}


Genomic DNA was extracted using the Isolate II Genomic DNA kit (Bioline) and 500 ng bisulfiteconverted using the EpiMark Bisulfite Conversion Kit (New England Biolabs). Primers were used to amplify regions of the BDNF promoter I (F: TGAGTGATGATTAAATGGGGATTG; R: BIOACTATTAACTCACATTTAAAAAACCATAAC; S: TGGGGATTGGGGGGA) and promoter IV (F: GATTTTGGTAATTCGTGTATTAGAGTGTT; R: BIO-AGATTAAATGGAGTTTTCGTTGAT; S: AATGGAGTTTTCGTTGATGGGGTGCA) using MyTaq HS mix PCR reagents (Bioline). The BDNF promoter I and promoter IV amplicons contained 5 and 9 CpG sites, respectively. Amplicons were processed on the Qiagen Q24 Workstation and sequenced on the Qiagen Q24 pyrosequencer. DNA methylation levels across each amplicon were averaged. See Supplemental Figure S1 for locations of the regions analysed.

\section{Statistical analysis}

All analyses were performed using IBM SPSS Statistics (v.25). BDNF isoform expression, protein and DNA methylation levels were log10 transformed prior to statistical analysis. Correlations between gene expression, DNA methylation and protein levels with donor age were performed using Pearson correlation tests. Correlations between gene expression, DNA methylation and protein levels were performed using Partial correlation tests, with donor age as a covariate. Differences in gene expression, DNA methylation and protein levels between rs6265 variant groups were assessed using independent student t-tests. Further, differences between groups while controlling for donor age were assessed using a one-way ANCOVA. Differences in gene expression, DNA methylation and protein levels between AD neuropathological groups were assessed using one-way ANOVA, as well as a one-way ANCOVA to control for age. Results are presented as mean and standard deviation, unless otherwise stated. Statistical significance was accepted when $\mathrm{P}<0.05$.

\section{$\underline{\text { Results }}$}

Clinical and pathological characteristics of the study population can be found in Table 1.

Table 1. Clinicopathological characteristics for the donor samples.

\begin{tabular}{lc}
\hline Characteristic & Mean (SD) \\
\hline Age at death (years) & $87.5(6.1)$ \\
Sex (male/female) & $21 / 46$ \\
Post-mortem delay (hours) $^{\mathrm{a}}$ & $76.1(43.7)$ \\
Brain weight (g) & $1207.4(137.4)$ \\
BDNF rs6265 (N) & \\
$\quad$ Val/Val & $39(58 \%)$ \\
\hline
\end{tabular}




\begin{tabular}{cc}
\hline Val/Met & $25(37 \%)$ \\
Met/Met & $3(5 \%)$ \\
Thal score (N) & $17(25 \%)$ \\
O (A0) & $11(16 \%)$ \\
1 (A1) & $6(9 \%)$ \\
2 (A2) & $17(25 \%)$ \\
3 (A2) & $9(13 \%)$ \\
4 (A3) & $7(10 \%)$ \\
5 (A3) & \\
Braak score (N) & $4(6 \%)$ \\
O (B0) & $11(16 \%)$ \\
I (B1) & $18(27 \%)$ \\
II (B1) & $13(19 \%)$ \\
III (B2) & $12(18 \%)$ \\
IV (B2) & $6(9 \%)$ \\
V (B3) & $2(3 \%)$ \\
VI (B3) & $18(18 \%)$ \\
CERAD score (N) & $18(27 \%)$ \\
None (C0) & \\
Sparse (C1) & $18 \%)$ \\
Moderate (C2) & \\
Frequent (C3) & \\
\hline (B) & \\
\hline
\end{tabular}

$$
\begin{aligned}
& { }^{a} N=60 \\
& { }^{b} N=43 \\
& { }^{c} N=66
\end{aligned}
$$

\section{Relationship between BDNF gene expression, DNA methylation and protein levels with age}

The association between BDNF exon I, IV and total long $3^{\prime}$ isoform expression with the age at death of donors was investigated (Figure 1). There was a negative association between expression of exon IV containing $(r=-0.291, P=0.020$; Figure $1 B)$ and total long $3^{\prime}(r=-0.354, P=0.004$; Figure $1 C)$ $B D N F$ isoforms with age, however, no relationships were evident for BDNF exon I containing isoform $(r=-0.201, P=0.149$; Figure $1 \mathrm{~A})$.

There were no associations between BDNF protein levels $(r=-0.143, P=0.256)$ or DNA methylation levels (promoter I: $r=-0.038, \mathrm{P}=0.761$; promoter IV: $r=0.177, \mathrm{P}=0.156$ ) with donor ages. 


\section{Correlations between BDNF gene expression, DNA methylation and protein levels}

The relationships between $B D N F$ gene expression, DNA methylation and protein levels can be seen in Table 2. Since donor age significantly correlated with BDNF gene expression, correlations were controlled for donor ages throughout.

Briefly, BDNF exon I isoform expression positively correlated with BDNF exon IV and total long 3' isoform expression. BDNF exon IV expression did not correlate with total long 3 ' variant expression. Promoter I DNA methylation negatively correlated with BDNF exon I isoform expression levels, however this correlation was lost $(\mathrm{p}=0.08)$ when account for RIN values (Supplementary Table S2). However, there were no associations between promoter IV methylation and BDNF exon IV isoform expression levels. Protein levels were not associated with either BNDF exon I, exon IV or total long 3'UTR RNA expression or DNA methylation levels.

Table 2. Partial correlation matrix, controlling for donor ages, between BDNF gene expression, DNA methylation and protein levels

\begin{tabular}{|c|c|c|c|c|c|c|}
\hline & \multicolumn{3}{|c|}{ Gene expression } & \multicolumn{2}{|c|}{ DNA methylation } & \multirow[b]{2}{*}{ Protein } \\
\hline & BDNFI & $B D N F I V$ & BDNF Total & Promoter I & Promoter IV & \\
\hline \multicolumn{7}{|l|}{$B D N F I$} \\
\hline$B D N F I V$ & $0.586 * * *$ & & & & & \\
\hline BDNF Total & $0.327^{*}$ & $-0.233+$ & & & & \\
\hline Promoter I & $-0.282 *$ & -0.181 & -0.206 & & & \\
\hline Promoter IV & -0.091 & 0.015 & -0.007 & 0.383 & & \\
\hline Protein & $0.251 \dagger$ & 0.018 & 0.054 & 0.074 & 0.044 & \\
\hline
\end{tabular}

Results displayed are partial correlation coefficient values. $+\mathrm{P}<0.10 .{ }^{*} \mathrm{P}<0.05 .{ }^{* * *} \mathrm{P}<0.001$.

Relationship between BDNF gene expression, DNA methylation and protein levels with rs6265 variant

The rs6265 variant was in Hardy-Weinberg equilibrium in the study population $\left(X^{2}=0.162, P=\right.$ $0.687)$.

To explore the differences in BDNF gene expression levels with the rs6265 variant, donors were stratified into Val-homozygotes and Met-allele carriers. There were no differences in BDNF exon I ( $\mathrm{t}$ $=-1.592, \mathrm{P}=0.118)$ and total long $3^{\prime}(\mathrm{t}=0.122, \mathrm{P}=0.904)$ variant gene expression levels between the two groups. However, the Met-allele carriers had significantly higher BDNF exon IV isoform expression compared to Val-homozygotes $(t=-2.640, P=0.010)$ (Figure 2). This difference remained 
after controlling for donor age at death $(F=6.455, P=0.014)$ and age AND RIN values $(F=7.229, P=$ $0.009)$.

There were no differences in BDNF protein levels $(t=0.446, P=0.657)$ or DNA methylation levels (promoter 1: $-0.435, \mathrm{P}=0.665$; promoter 4 : $-0.755, \mathrm{P}=0.453$ ) between rs6265 variants.

\section{Relationship between BDNF gene expression, DNA methylation and protein levels with}

\section{Alzheimer's disease pathology}

To investigate the difference in BDNF gene expression with AD pathology, donors were stratified based on the NIA-AA "ABC" score, which considers the amyloid plaque, neuritic plaque and neurofibrillary tangle scores. These groups were Not, Low, Intermediate and High AD neuropathological change.

Overall, there were differences in $B D N F$ total long $3^{\prime}$ isoform gene expression levels between $A D$ pathological groups $(F=3.074, P=0.035)$. Specifically, inter-group comparisons revealed a significant downregulation of BDNF total long $3^{\prime}$, isoform expression in the Low AD group, compared to the Not $A D$ group $(P=0.021)$ (Figure 3$)$.

This difference was also apparent when accounting for donor age at death (overall comparison: $\mathrm{F}=$ 3.323, $\mathrm{P}=0.026$; post-hoc comparison: $\mathrm{P}=0.021$ ), however when including age AND RIN values, there were no differences $(F=1.909, P=0.139)$.

There were no differences in $B D N F$ exon I $(\mathrm{F}=2.766, \mathrm{P}=0.053)$ or $I V(\mathrm{~F}=0.405, \mathrm{P}=0.750)$ isoform expression levels between the AD neuropathological groups. Further, there were no differences in protein $(\mathrm{F}=0.953, \mathrm{P}=0.421)$ or DNA methylation (promoter $1: \mathrm{F}=1.019, \mathrm{P}=0.391$; promoter $4: \mathrm{F}=$ $1.009, P=0.396)$ levels between groups.

\section{Discussion}

In the prefrontal cortex, BDNF gene expression was associated with donor age, rs6265 carrier status and early $A D$ neuropathology in a variant-specific manner. These associations were independent of any influences of DNA methylation or protein levels. Thus, we provide further evidence to the complex mechanisms dysregulating central BDNF during ageing and neurodegeneration.

The majority of research investigating age associations of BDNF levels in humans has focussed on peripheral measures. Specifically, many reports suggest a gradual reduction in plasma and serum concentrations during ageing $[6,26-28]$. There is, however, limited knowledge of $B D N F$ regulation in human brain tissue across ages. We report significant reductions of BDNF exon IV and total long 3', but not exon I, containing isoforms between the ages of 72 and 104 years old. This corroborates 
findings from that of $\mathrm{O}$ and colleagues, who also reported reductions in total and exon $I V$ containing RNAs in the prefrontal cortex, without any differences in the exon I-containing transcript, between ages 16 to 96 years [7]. Because only exon IX contains the coding region, all the different exon-containing RNA transcripts will be translated to a single species of BDNF polypeptide. It is hypothesised that this sophisticated gene serves to fine-tune a dynamic transcriptional regulation in different cell types by different neuronal activities. For example, it has been shown in rodent studies that fear conditioning increased both BDNF exon I and IV containing RNA in hippocampus, but only exon IV in the CA1 region $[29,30]$ while fear memory extinction elevated BDNF exon I and IV in prefrontal cortex [31]. Interestingly, a study on contextual fear conditioning caused a significant increase of BDNF exon I in WT hippocampus while the levels of exon IV remained unchanged [32]. This highlights that the different exons can be differently regulated. Mechanistically, within BDNF exon IV promoter three calcium responsive elements (i.e. CaRE1, 2 and 3) have been identified regulating calcium-mediated BDNF IV transcription, while in promoter I there is one CRE in promoter I that can be differently regulated by different $\mathrm{Ca} 2+-$ stimulated protein kinases and other $\mathrm{Ca} 2+-$ stimulated intracellular molecules [33]. The calcium hypothesis of aging [34,35], hypothesises a dysregulation of intracellular $\mathrm{Ca} 2+$ homeostasis is a primary factor contributing to aging-related learning and memory impairments in humans and other mammals, that may further relate to AD. Perhaps this may reflect differential regulation of BDNF transcritps. Interestingly a NF-kappaB [36] site and an E-box [37] have been identified in exon IV promoter that again allow differential regulation and may again reflect age-related changes in these regulatory factors in the brain [38](Zhang et al).

We report variant-specific associations with the rs6265 variant. Specifically, Met-carriers had an upregulation of BDNF transcripts containing exon IV, but not exon I or total long 3'UTR transcripts, compared to Val-homozygotes. The effect of the rs6265 polymorphism on BDNF gene expression is largely unknown [39]. A previous study involving over 500 prefrontal cortex donor samples revealed no differences of BDNF gene expression between rs6265 genotypes [40]. Despite the superior statistical power in this analysis, expression levels of different transcript variants were not reported, rather, only total expression. Given our preliminary insight suggesting the influence of the rs6265 variant may be transcript-specific in BDNF expression, it would be interesting to replicate our analysis in this population.

The reduction in $B D N F$ expression with $A D$ neuropathology is in agreement with other reports analysing prefrontal [40], frontal [41], parietal [42] and temporal [41] cortical tissues, as well as the hippocampus [41]. Interestingly, our results further suggest the association between expressions and neuropathology magnitude may be stage specific. Specifically, those with early $A D$ 
neuropathology having significant $B D N F$ downregulation seem to be particularly affected. Increased neuroinflammation is suspected to have a major role in AD progression. The predominant hypothesis suggests levels of neuroinflammation peaks early on, possibly reflecting an initial antiinflammatory response, followed by a second peak during conversion from $M C l$ to $A D$, which may indicate a pro-inflammatory shift $[43,44]$. This complex relationship may be related to the microglial reaction following the deposition and propagation of amyloid and hyperphosphorylated tau pathologies [45]. Numerous studies demonstrate that neuroinflammation in turn affects the expression of BDNF within the brain; therefore, reduction of BDNF expression and function may be a key mechanism underlying the negative impact of pro-inflammatory cytokines on neuroplasticity [46].

There are a number of limitations to this study. Variations in postmortem times and RIN values (Supplementary Table 1) impacted some of the results such as BDNF promoter I methylation and exon I-containing transcript expression, that when we adjusted for, significance was lost. Also, some RNA samples were unable to clearly measured for all transcripts from the total 67 subjects (i.e. exon I, $n=53$; exon IV, $n=64$; long 3'UTR, $n=66$ ). A further confounding variable is that the prefrontal cortex samples also contain relatively heterogeneous cell populations that were not able to control for. Finally, we only investigated specific promoters and transcripts containing exon I, IV and long 3'UTR, though it would be interesting to investigate further regions of the BDNF gene and more complete coverage of all the different transcripts.

\section{Conclusion}

In conclusion, we report prefrontal cortex BDNF gene expression is associated with ageing, rs6265 carrier status and AD neuropathology in a variant-specific manner. This dysregulation seems to be independent of DNA methylation influences at the I and IV promoters. These results add further evidence to the complex regulation of the BDNF gene within the cortex.

\section{Conflict of interest / Disclosure statement}

The authors have no conflict of interests to report.

\section{$\underline{\text { References }}$}

[1] Kang H, Schuman EM (1995) Long-lasting neurotrophin-induced enhancement of synaptic transmission in the adult hippocampus. Science 267, 1658-62. 
[2] Figurov A, Pozzo-Miller LD, Olafsson P, Wang T, Lu B (1996) Regulation of synaptic responses to high-frequency stimulation and LTP by neurotrophins in the hippocampus. Nature 381, 706-709.

[3] McKinney BC, Lin C-W, Oh H, Tseng GC, Lewis DA, Sibille E (2015) Hypermethylation of BDNF and SST Genes in the Orbital Frontal Cortex of Older Individuals: A Putative Mechanism for Declining Gene Expression with Age. Neuropsychopharmacology 40, 2604-2613.

[4] Lu B, Nagappan G, Lu Y (2014) BDNF and Synaptic Plasticity, Cognitive Function, and Dysfunction. In, pp. 223-250.

[5] Komulainen P, Pedersen M, Hänninen T, Bruunsgaard H, Lakka TA, Kivipelto $M$, Hassinen $M$, Rauramaa TH, Pedersen BK, Rauramaa R (2008) BDNF is a novel marker of cognitive function in ageing women: the DR's EXTRA Study. Neurobiol. Learn. Mem. 90, 596-603.

[6] Erickson KI, Prakash RS, Voss MW, Chaddock L, Heo S, McLaren M, Pence BD, Martin SA, Vieira VJ, Woods JA, McAuley E, Kramer AF (2010) Brain-Derived Neurotrophic Factor Is Associated with Age-Related Decline in Hippocampal Volume. J. Neurosci. 30, 5368-5375.

[7] Oh H, Lewis DA, Sibille E (2016) The Role of BDNF in Age-Dependent Changes of Excitatory and Inhibitory Synaptic Markers in the Human Prefrontal Cortex. Neuropsychopharmacology 41, 3080-3091.

[8] Pruunsild P, Kazantseva A, Aid T, Palm K, Timmusk T (2007) Dissecting the human BDNF locus: bidirectional transcription, complex splicing, and multiple promoters. Genomics 90, 397-406.

[9] An JJ, Gharami K, Liao G-Y, Woo NH, Lau AG, Vanevski F, Torre ER, Jones KR, Feng Y, Lu B, Xu B (2008) Distinct role of long 3' UTR BDNF mRNA in spine morphology and synaptic plasticity in hippocampal neurons. Cell 134, 175-87.

[10] Cattaneo A, Cattane N, Begni V, Pariante CM, Riva MA (2016) The human BDNF gene: peripheral gene expression and protein levels as biomarkers for psychiatric disorders. Transl. Psychiatry 6, e958-e958.

[11] Hing B, Sathyaputri L, Potash JB (2018) A comprehensive review of genetic and epigenetic mechanisms that regulate $B D N F$ expression and function with relevance to major depressive disorder. Am. J. Med. Genet. Part B Neuropsychiatr. Genet. 177, 143-167.

[12] Ikegame T, Bundo M, Murata Y, Kasai K, Kato T, Iwamoto K (2013) DNA methylation of the BDNF gene and its relevance to psychiatric disorders. J. Hum. Genet. 58, 434-438. 
[13] Keller S, Sarchiapone M, Zarrilli F, Videtic A, Ferraro A, Carli V, Sacchetti S, Lembo F, Angiolillo A, Jovanovic N, Pisanti F, Tomaiuolo R, Monticelli A, Balazic J, Roy A, Marusic A, Cocozza S, Fusco A, Bruni CB, Castaldo G, Chiariotti L (2010) Increased BDNF promoter methylation in the Wernicke area of suicide subjects. Arch. Gen. Psychiatry 67, 258-67.

[14] Xie B, Xu Y, Liu Z, Liu W, Jiang L, Zhang R, Cui D, Zhang Q, Xu S (2017) Elevation of Peripheral BDNF Promoter Methylation Predicts Conversion from Amnestic Mild Cognitive Impairment to Alzheimer's Disease: A 5-Year Longitudinal Study. J. Alzheimer's Dis. 56, 391-401.

[15] Chang L, Wang Y, Ji H, Dai D, Xu X, Jiang D, Hong Q, Ye H, Zhang X, Zhou X, Liu Y, Li J, Chen Z, Li Y, Zhou D, Zhuo R, Zhang Y, Yin H, Mao C, Duan S, Wang Q (2014) Elevation of Peripheral BDNF Promoter Methylation Links to the Risk of Alzheimer's Disease. PLoS One 9, e110773.

[16] Nagata T, Kobayashi N, Ishii J, Shinagawa S, Nakayama R, Shibata N, Kuerban B, Ohnuma T, Kondo K, Arai H, Yamada H, Nakayama K (2015) Association between DNA Methylation of the BDNF Promoter Region and Clinical Presentation in Alzheimer's Disease. Dement. Geriatr. Cogn. Dis. Extra 5, 64-73.

[17] Xie B, Liu Z, Liu W, Jiang L, Zhang R, Cui D, Zhang Q, Xu S (2017) DNA Methylation and Tag SNPs of the BDNF Gene in Conversion of Amnestic Mild Cognitive Impairment into Alzheimer's Disease: A Cross-Sectional Cohort Study. J. Alzheimer's Dis. 58, 263-274.

[18] Carboni L, Lattanzio F, Candeletti S, Porcellini E, Raschi E, Licastro F, Romualdi P (2015) Peripheral leukocyte expression of the potential biomarker proteins Bdnf, Sirt1, and Psen1 is not regulated by promoter methylation in Alzheimer's disease patients. Neurosci. Lett. 605, $44-48$.

[19] Rao JS, Keleshian VL, Klein S, Rapoport SI (2012) Epigenetic modifications in frontal cortex from Alzheimer's disease and bipolar disorder patients. Transl. Psychiatry 2, e132.

[20] Rabbitt PMA, Mclnnes L, Diggle P, Holland F, Bent N, Abson V, Pendleton N, Horan M (2004) The University of Manchester Longitudinal Study of Cognition in Normal Healthy Old Age, 1983 through 2003. Aging, Neuropsychol. Cogn. 11, 245-279.

[21] Robinson AC, Davidson YS, Horan MA, Pendleton N, Mann DMA (2018) Pathological Correlates of Cognitive Impairment in The University of Manchester Longitudinal Study of Cognition in Normal Healthy Old Age. J. Alzheimer's Dis. 64, 483-496.

[22] Hyman BT, Phelps CH, Beach TG, Bigio EH, Cairns NJ, Carrillo MC, Dickson DW, Duyckaerts C, Frosch MP, Masliah E, Mirra SS, Nelson PT, Schneider JA, Thal DR, Thies B, Trojanowski JQ, 
Vinters H V, Montine TJ (2012) National Institute on Aging-Alzheimer's Association guidelines for the neuropathologic assessment of Alzheimer's disease. Alzheimers. Dement. 8, 1-13.

[23] Vandesompele J, De Preter K, Pattyn F, Poppe B, Van Roy N, De Paepe A, Speleman F (2002) Accurate normalization of real-time quantitative RT-PCR data by geometric averaging of multiple internal control genes. Genome Biol. 3, RESEARCH0034.

[24] Bradburn S, McPhee J, Bagley L, Carroll M, Slevin M, Al-Shanti N, Barnouin Y, Hogrel J-Y, Pääsuke M, Gapeyeva H, Maier A, Sipilä S, Narici M, Robinson A, Mann D, Payton A, Pendleton N, Butler-Browne G, Murgatroyd C (2018) Dysregulation of C-X-C motif ligand 10 during aging and association with cognitive performance. Neurobiol. Aging 63, 54-64.

[25] Bradburn S, McPhee JS, Bagley L, Sipila S, Stenroth L, Narici MV, Pääsuke M, Gapeyeva H, Osborne G, Sassano L, Meskers CGM, Maier AB, Hogrel J-Y, Barnouin Y, Butler-Browne G, Murgatroyd C (2016) Association between osteocalcin and cognitive performance in healthy older adults. Age Ageing 45, 844-849.

[26] Passaro A, Dalla Nora E, Morieri ML, Soavi C, Sanz JM, Zurlo A, Fellin R, Zuliani G (2015) BrainDerived Neurotrophic Factor Plasma Levels: Relationship With Dementia and Diabetes in the Elderly Population. Journals Gerontol. Ser. A Biol. Sci. Med. Sci. 70, 294-302.

[27] Lommatzsch M, Zingler D, Schuhbaeck K, Schloetcke K, Zingler C, Schuff-Werner P, Virchow JC (2005) The impact of age, weight and gender on BDNF levels in human platelets and plasma. Neurobiol. Aging 26, 115-123.

[28] Golden E, Emiliano A, Maudsley S, Windham BG, Carlson OD, Egan JM, Driscoll I, Ferrucci L, Martin B, Mattson MP (2010) Circulating Brain-Derived Neurotrophic Factor and Indices of Metabolic and Cardiovascular Health: Data from the Baltimore Longitudinal Study of Aging. PLoS One 5, e10099.

[29] Lubin FD, Roth TL, Sweatt JD (2008) Epigenetic Regulation of bdnf Gene Transcription in the Consolidation of Fear Memory. J. Neurosci. 28, 10576-10586.

[30] Fuchikami M, Yamamoto S, Morinobu S, Takei S, Yamawaki S (2010) Epigenetic Regulation of BDNF Gene in Response to Stress. Psychiatry Investig. 7, 251.

[31] Rattiner LM, Davis M, Ressler KJ (2004) Differential regulation of brain-derived neurotrophic factor transcripts during the consolidation of fear learning. Learn. Mem. 11, 727-731.

[32] Ou L-C, Gean P-W (2007) Transcriptional Regulation of Brain-Derived Neurotrophic Factor in the Amygdala during Consolidation of Fear Memory. Mol. Pharmacol. 72, 350-358. 
[33] Zheng F, Zhou X, Moon C, Wang H (2012) Regulation of brain-derived neurotrophic factor expression in neurons. Int. J. Physiol. Pathophysiol. Pharmacol. 4, 188-200.

[34] Khachaturian ZS (1994) Calcium hypothesis of Alzheimer's disease and brain aging. Ann. N. Y. Acad. Sci. 747, 1-11.

[35] Khachaturian ZS Hypothesis on the regulation of cytosol calcium concentration and the aging brain. Neurobiol. Aging 8, 345-6.

[36] Lipsky RH, Xu K, Zhu D, Kelly C, Terhakopian A, Novelli A, Marini AM (2001) Nuclear factor kappaB is a critical determinant in N-methyl-D-aspartate receptor-mediated neuroprotection. J. Neurochem. 78, 254-64.

[37] Jiang X, Tian F, Du Y, Copeland NG, Jenkins NA, Tessarollo L, Wu X, Pan H, Hu X-Z, Xu K, Kenney H, Egan SE, Turley H, Harris AL, Marini AM, Lipsky RH (2008) BHLHB2 controls Bdnf promoter 4 activity and neuronal excitability. J. Neurosci. 28, 1118-30.

[38] Zhang G, Li J, Purkayastha S, Tang Y, Zhang H, Yin Y, Li B, Liu G, Cai D (2013) Hypothalamic programming of systemic ageing involving IKK- $\beta$, NF-KB and GnRH. Nature 497, 211-6.

[39] Tsai S-J (2018) Critical Issues in BDNF Val66Met Genetic Studies of Neuropsychiatric Disorders. Front. Mol. Neurosci. 11, 156.

[40] Buchman AS, Yu L, Boyle PA, Schneider JA, De Jager PL, Bennett DA (2016) Higher brain BDNF gene expression is associated with slower cognitive decline in older adults. Neurology 86, 735-741.

[41] Li G-D, Bi R, Zhang D-F, Xu M, Luo R, Wang D, Fang Y, Li T, Zhang C, Yao Y-G (2017) Femalespecific effect of the BDNF gene on Alzheimer's disease. Neurobiol. Aging 53, 192.e11192.e19.

[42] Garzon D, Yu G, Fahnestock M (2004) A new brain-derived neurotrophic factor transcript and decrease inbrain-derived neurotrophic factor transcripts 1, 2 and 3 in Alzheimer's disease parietal cortex. J. Neurochem. 82, 1058-1064.

[43] Calsolaro V, Edison P (2016) Neuroinflammation in Alzheimer's disease: Current evidence and future directions. Alzheimer's Dement. 12, 719-732.

[44] Fan Z, Aman Y, Ahmed I, Chetelat G, Landeau B, Ray Chaudhuri K, Brooks DJ, Edison P (2015) Influence of microglial activation on neuronal function in Alzheimer's and Parkinson's disease dementia. Alzheimer's Dement. 11, 608-621.e7. 
[45] Morales I, Jiménez JM, Mancilla M, Maccioni RB (2013) Tau oligomers and fibrils induce activation of microglial cells. J. Alzheimers. Dis. 37, 849-56.

[46] Calabrese F, Rossetti AC, Racagni G, Gass P, Riva MA, Molteni R (2014) Brain-derived neurotrophic factor: a bridge between inflammation and neuroplasticity. Front. Cell. Neurosci. 8, 


\section{Figure legends}
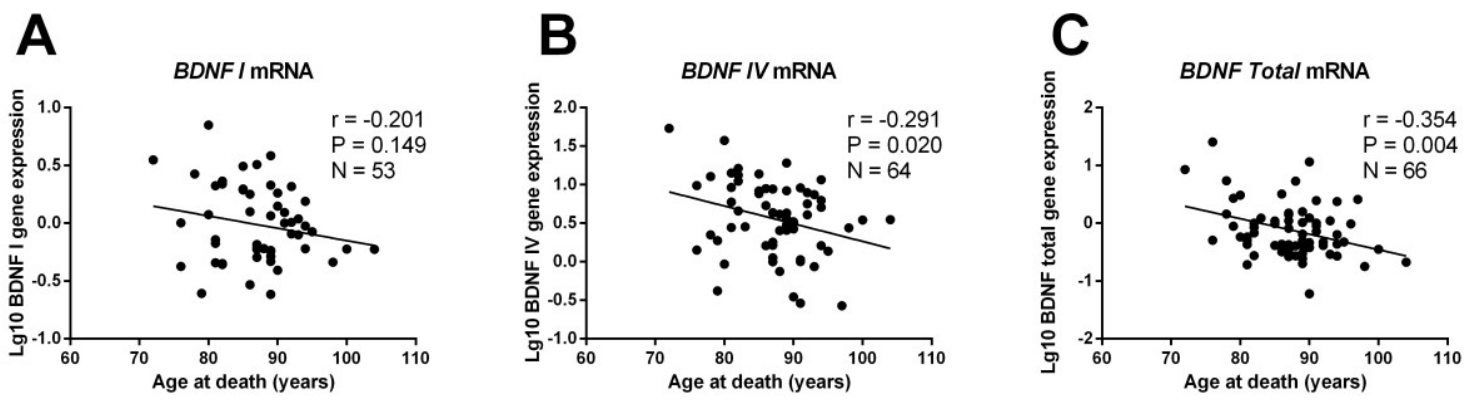

Figure 1. Associations between donor age at death with A: BDNF I variant, B: BDNF IV variant and C: BDNF total mRNA expression. 

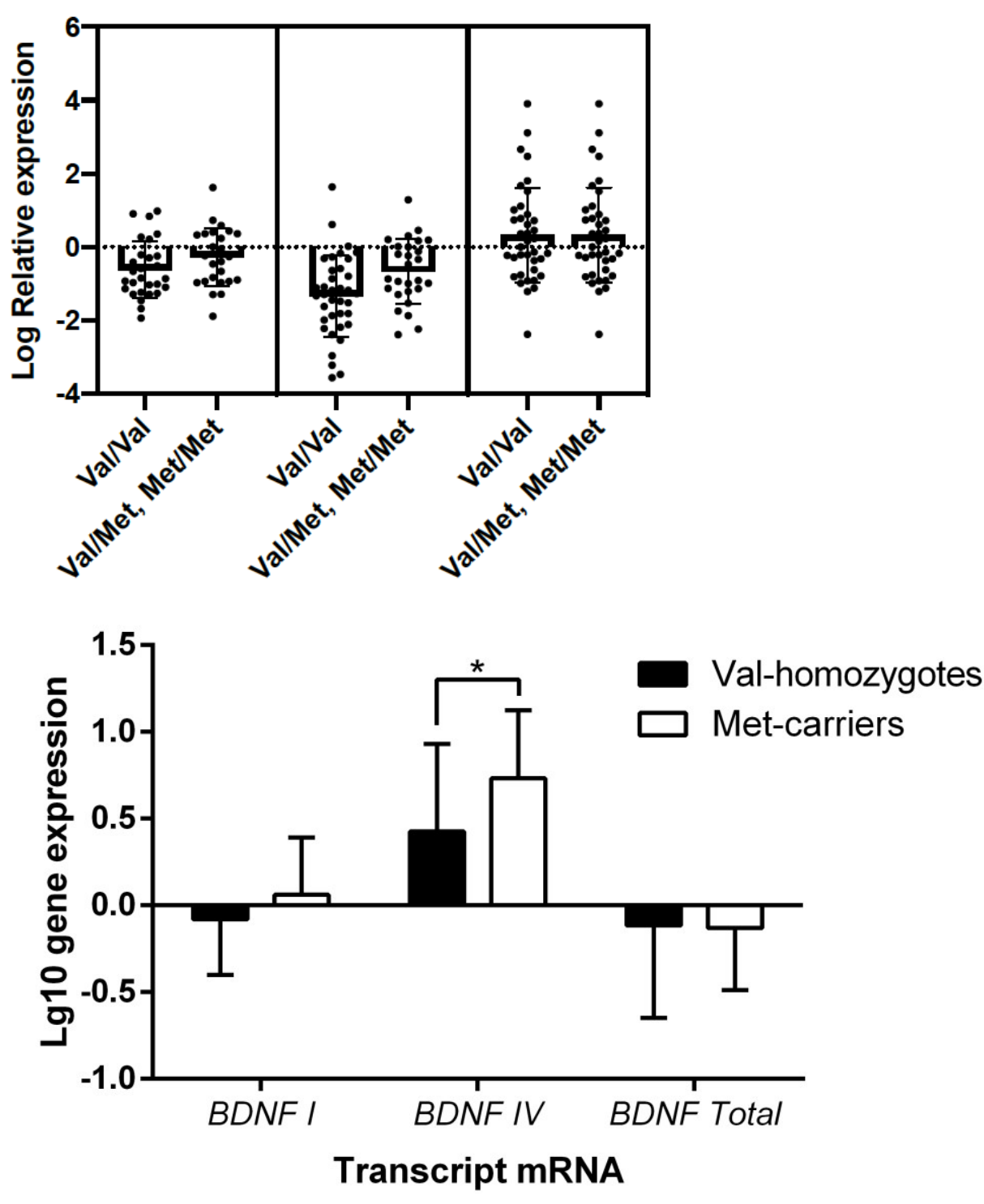

Figure 2. Difference in BDNF gene expression between rs6265 Val-homozygotes and Met-carriers. $B D N F$ I: Val-homozygotes $\mathrm{N}=28$, Met-carriers $\mathrm{N}=25$. BDNF IV: Val-homozygotes $\mathrm{N}=37$, Metcarriers $\mathrm{N}=27$. BDNF total: Val-homozygotes $\mathrm{N}=38$, Met-carriers $\mathrm{N}=28 * \mathrm{P}<0.05$. 


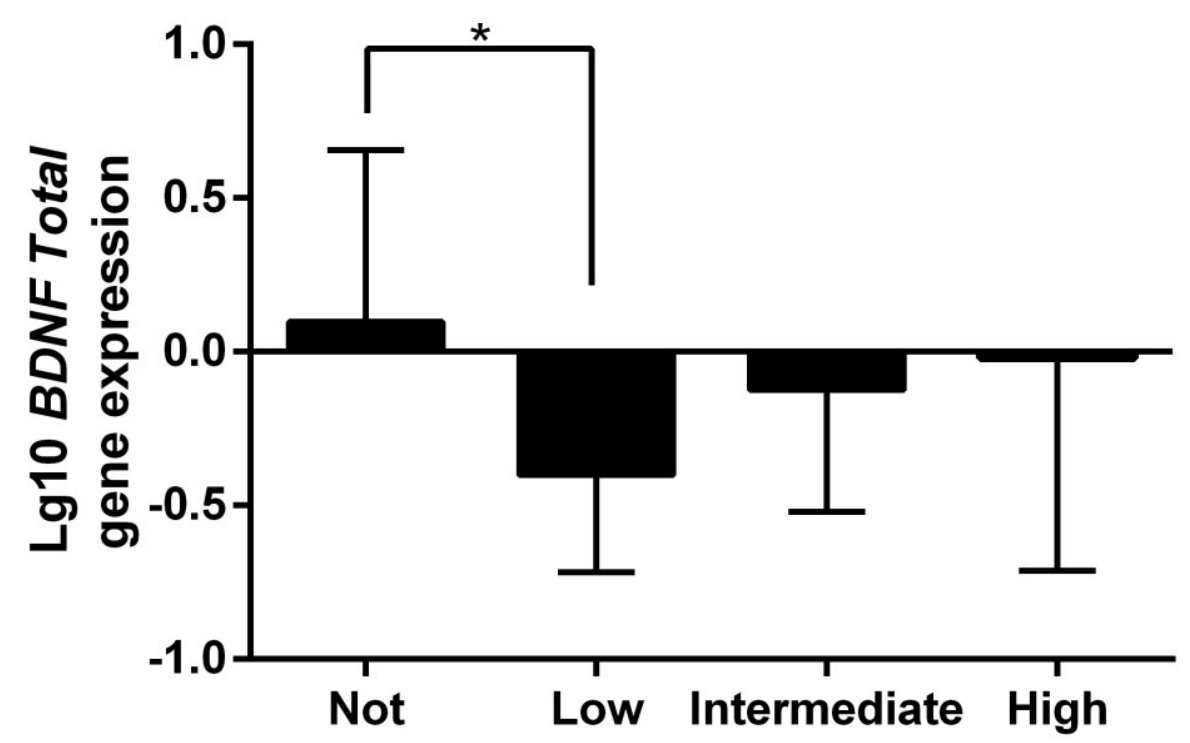

Figure 3. Difference in BDNF total variant gene expression between $A D$ neuropathology groups. $N=$ 16 (Not), 14 (Low), 26 (Intermediate), 5 (High). * P $<0.05$.

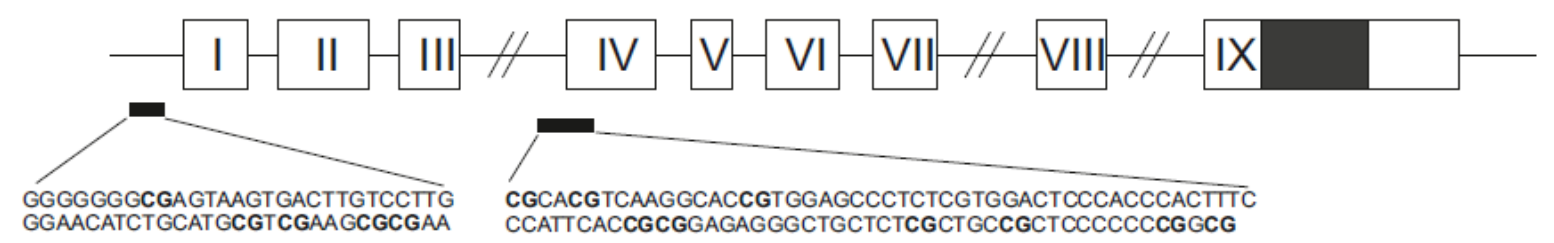

Supplementary Figure 1. Schematic of the Human BDNF gene. Untranslated first exons are numbered I-VIII and the coding sequence for pro-BDNF is shaded black. Sequences of regions of promoters I and IV investigated for DNA methylation [Exon I, chr11:27,722,265-27,722,319; Exon IV, chr11:27,701,578-27,701,672 (Hg38)] are shown with CpG residues in bold.

Supplemental Table 1. Sample details. 


\begin{tabular}{|c|c|c|c|c|c|c|}
\hline $\begin{array}{l}\text { Patient } \\
\text { _Code }\end{array}$ & $\begin{array}{l}\text { Age_at_ } \\
\text { death }\end{array}$ & $\begin{array}{l}\text { Gende } \\
r\end{array}$ & $\begin{array}{l}\text { Brain_ } \\
\text { Weight }\end{array}$ & PMD & $\begin{array}{l}\text { Primary_Pathology_Diagnosis_D } \\
\text { escription }\end{array}$ & RIN_Value \\
\hline 22708 & 91 & $\mathrm{~F}$ & 1216.00 & 133.0 & Age changes only & 3.20 \\
\hline 11052 & 94 & $\mathrm{~F}$ & 946.00 & 111.0 & Age changes only & 5.30 \\
\hline 10540 & 98 & $\mathrm{~F}$ & 1029.00 & 84.0 & Possible AD & 6.10 \\
\hline 11383 & 100 & $\mathrm{~F}$ & 1058.00 & 61.5 & CAA & 4.60 \\
\hline 21337 & 86 & $\mathrm{~F}$ & 1334.00 & 96.0 & $A D$ & 6.10 \\
\hline 12284 & 96 & $\mathrm{~F}$ & - & 154.0 & Moderate AD pathology & 2.30 \\
\hline 11060 & 83 & $\mathrm{~F}$ & 1108.00 & 94.0 & Mild AD changes in temporal lobe & 2.30 \\
\hline 11299 & 89 & $\mathrm{M}$ & 1070.00 & 36.0 & $\begin{array}{l}\text { Age-related tau astrogliopathy } \\
\text { with hippocampal sclerosis and } \\
\text { secondary TDP-43 }\end{array}$ & 4.90 \\
\hline 22625 & 91 & $\mathrm{M}$ & 1157.00 & 93.0 & Age changes only & 4.00 \\
\hline 10192 & 97 & M & 1252.00 & 120.5 & $\begin{array}{l}\text { Argyrophilic Grain Disease with } \\
\text { v.mild AD-like tau }\end{array}$ & 2.60 \\
\hline 20274 & 94 & $\mathrm{~F}$ & 1166.00 & 86.0 & Early/Incipient AD & 2.80 \\
\hline 11618 & 79 & $\mathrm{~F}$ & - & 116.0 & Argyrophilic Grain Disease & 3.40 \\
\hline 10502 & 81 & $\mathrm{~F}$ & 1160.00 & 113.5 & Probable AD & 5.30 \\
\hline 10544 & 89 & $\mathrm{~F}$ & 1450.00 & 144.0 & CAA (?)moderate SVD & 2.90 \\
\hline 11971 & 81 & $\mathrm{~F}$ & 1363.00 & 44.0 & Early/incipient AD & 4.50 \\
\hline 23096 & 76 & $\mathrm{~F}$ & 1204.00 & 47.0 & Mild AD changes in temporal lobe & 2.30 \\
\hline 22091 & 82 & $\mathrm{~F}$ & 1020.00 & 61.0 & Age changes only & 2.70 \\
\hline 12762 & 90 & $\mathrm{~F}$ & 1217.00 & 103.0 & Age changes only & 4.40 \\
\hline 22105 & 89 & $\mathrm{M}$ & - & 128.0 & Incipient AD & 5.60 \\
\hline 12504 & 90 & $\mathrm{M}$ & - & 156.0 & Age changes only & \#NULL! \\
\hline 10640 & 104 & $\mathrm{~F}$ & 1289.00 & 78.0 & $A D$ & 3.10 \\
\hline 22194 & 88 & $\mathrm{~F}$ & 1129.00 & 4.0 & Early limbic predominant DLB & 5.90 \\
\hline 22867 & 93 & $\mathrm{~F}$ & 1133.00 & 70.5 & Probable AD & 2.50 \\
\hline 21297 & 85 & $\mathrm{M}$ & - & 187.5 & Mild CAA & 4.20 \\
\hline 20088 & 90 & $\mathrm{~F}$ & - & 41.5 & Age changes only & 2.30 \\
\hline 21179 & 86 & $\mathrm{M}$ & 1100.00 & 26.0 & $A D$ & 2.30 \\
\hline 11845 & 89 & $F$ & - & 36.0 & CVD & 2.30 \\
\hline 21683 & 90 & $\mathrm{~F}$ & 1050.00 & 39.0 & Age changes only & 6.30 \\
\hline
\end{tabular}




\begin{tabular}{|c|c|c|c|c|c|c|}
\hline 22340 & 76 & $\mathrm{~F}$ & 1359.00 & 129.5 & Age changes only & 6.50 \\
\hline 12698 & 87 & $\mathrm{~F}$ & - & 39.0 & Age changes only & 5.80 \\
\hline 11240 & 89 & $M$ & - & 27.0 & Age changes only & 3.30 \\
\hline 11379 & 80 & $\mathrm{~F}$ & 1000.00 & 81.0 & Probable AD & 4.60 \\
\hline 20845 & 95 & $\mathrm{~F}$ & 1116.00 & 88.0 & Possible AD & 3.40 \\
\hline 22110 & 85 & $M$ & - & 12.0 & Age changes only & 5.00 \\
\hline 21493 & 91 & $M$ & - & - & Moderate SVD & 3.30 \\
\hline 21092 & 87 & $\mathrm{~F}$ & 1152.00 & 24.0 & Age changes only & 2.50 \\
\hline 11662 & 81 & $\mathrm{~F}$ & 1250.00 & - & Incipient AD & 2.30 \\
\hline 10719 & 72 & $\mathrm{~F}$ & 1230.00 & - & Incipient AD & 2.60 \\
\hline 20429 & 92 & $M$ & - & 24.0 & Moderate CVD & 3.40 \\
\hline 11802 & 89 & $\mathrm{~F}$ & - & 134.0 & Mild AD pathology & 5.10 \\
\hline 11176 & 82 & $\mathrm{~F}$ & 1174.00 & 46.0 & Mild DLB & 4.50 \\
\hline 11427 & 78 & $M$ & - & 144.0 & Age changes only & 5.70 \\
\hline 11550 & 94 & $M$ & 1550.00 & 42.0 & CAA? & 6.80 \\
\hline 20428 & 82 & $\mathrm{~F}$ & - & 96.0 & Probable AD & 3.20 \\
\hline 11341 & 92 & $M$ & 1270.00 & 48.0 & Early/incipient AD & 2.90 \\
\hline 22691 & 79 & $\mathrm{~F}$ & 1290.00 & - & Incipient AD & 2.30 \\
\hline 22083 & 87 & $M$ & - & 120.0 & Mild AD & 2.45 \\
\hline 20402 & 89 & $\mathrm{~F}$ & - & 72.0 & $A D$ & 4.50 \\
\hline 20382 & 78 & $\mathrm{~F}$ & - & - & Probable AD & 2.50 \\
\hline 11508 & 94 & $\mathrm{~F}$ & 1150.00 & - & Age changes only & 3.40 \\
\hline 10004 & 86 & $M$ & - & 18.0 & DLB & 2.70 \\
\hline 12755 & 89 & $\mathrm{~F}$ & 1351.00 & 56.0 & Moderate AD pathology & 2.60 \\
\hline 22272 & 93 & $M$ & 1348.00 & 39.0 & Mild transitional DLB & 2.30 \\
\hline 22738 & 88 & $\mathrm{~F}$ & - & 72.0 & Mild CVD & 2.70 \\
\hline 12022 & 82 & $\mathrm{~F}$ & 1210.00 & 120.0 & Mild AD/PD path. & 2.20 \\
\hline 10664 & 90 & $M$ & 1134.00 & 114.5 & Corticobasal degeneration & 4.80 \\
\hline 12033 & 91 & $M$ & 1520.00 & 43.5 & Mild SVD & 4.00 \\
\hline 10772 & 87 & $\mathrm{~F}$ & 1019.00 & 60.0 & $A D$ & 3.10 \\
\hline 20935 & 92 & $\mathrm{~F}$ & - & 37.0 & Age changes only & 2.40 \\
\hline 10132 & 81 & $\mathrm{~F}$ & 1210.00 & 41.0 & Age changes only & 3.50 \\
\hline 12221 & 87 & $M$ & 1410.00 & 80.0 & CVD & 2.40 \\
\hline
\end{tabular}




\begin{tabular}{|l|l|l|l|l|l|l|}
\hline 21664 & 90 & F & - & 6.0 & Possible AD & 2.40 \\
\hline 10118 & 87 & F & 1178.00 & 87.0 & Mild AD path. in temporal lobe & 4.70 \\
\hline 11426 & 88 & F & - & 72.0 & AD & 2.60 \\
\hline 12413 & 80 & M & 1240.00 & - & Incipient AD & 2.20 \\
\hline 11322 & 87 & F & 1305.00 & 120.0 & PD & 6.50 \\
\hline 10954 & 85 & F & - & 12.0 & Mild CAA & 2.50 \\
\hline
\end{tabular}

Alzheimers Disease, AD; Parkinsons Disease, PD; cerebral amyloid angiopathy, CAA; cerebrovascular disease, CVD;

Supplemental Table 2. Pearson correlations between BDNF gene expression, methylation and protein with RIN and PMD times

Correlations

LgBDNF_Transcri LgBDNF_Transcri LgBDNF_Total_Ex LgM pt1_Exp_New pt4_Exp_New p New

\begin{tabular}{|c|c|c|c|c|}
\hline LgBDNF_Trans & Pearson Correlation & 1 & $.608^{* *}$ & $.371^{* *}$ \\
\hline cript1_Exp_Ne & Sig. (2-tailed) & & .000 & .006 \\
\hline W & $\mathrm{N}$ & 53 & 53 & 53 \\
\hline \multirow{3}{*}{$\begin{array}{l}\text { LgBDNF_Trans } \\
\text { cript4_Exp_Ne } \\
\text { w }\end{array}$} & Pearson Correlation & $.608^{* *}$ & 1 & -.106 \\
\hline & Sig. (2-tailed) & .000 & & .406 \\
\hline & $\mathrm{N}$ & 53 & 64 & 64 \\
\hline \multirow{3}{*}{$\begin{array}{l}\text { LgBDNF_Total__ } \\
\text { Exp_New }\end{array}$} & Pearson Correlation & $.371^{* *}$ & -.106 & 1 \\
\hline & Sig. (2-tailed) & .006 & .406 & \\
\hline & $\mathrm{N}$ & 53 & 64 & 66 \\
\hline \multirow{3}{*}{$\begin{array}{l}\text { LgMeth_Proml_ } \\
\text { Avg }\end{array}$} & Pearson Correlation & -.268 & -.162 & -.179 \\
\hline & Sig. (2-tailed) & .054 & .205 & .153 \\
\hline & $\mathrm{N}$ & 52 & 63 & 65 \\
\hline \multirow{3}{*}{$\begin{array}{l}\text { LgMeth_Proml } \\
\text { V_Avg }\end{array}$} & Pearson Correlation & -.124 & -.038 & -.069 \\
\hline & Sig. (2-tailed) & .378 & .768 & .585 \\
\hline & $\mathrm{N}$ & 53 & 64 & 65 \\
\hline \multirow[t]{3}{*}{ LgBDNFprotein } & Pearson Correlation & .272 & .058 & .101 \\
\hline & Sig. (2-tailed) & .051 & .652 & .427 \\
\hline & $\mathrm{N}$ & 52 & 62 & 64 \\
\hline \multirow[t]{3}{*}{ RNA RIN Value } & Pearson Correlation & -.058 & .244 & $-.475^{\star *}$ \\
\hline & Sig. (2-tailed) & .678 & .052 & .000 \\
\hline & $\mathrm{N}$ & 53 & 64 & 66 \\
\hline \multirow{2}{*}{$\begin{array}{l}\text { Postmortum } \\
\text { delay (hours) }\end{array}$} & Pearson Correlation & .037 & -.066 & -.043 \\
\hline & Sig. (2-tailed) & .799 & .626 & .746 \\
\hline
\end{tabular}


**. Correlation is significant at the 0.01 level (2-tailed).

*. Correlation is significant at the 0.05 level (2-tailed).

Supplemental Table 3. Partial correlation matrix, controlling for donor ages and RIN values, between BDNF gene expression, DNA methylation and protein levels

\begin{tabular}{|c|c|c|c|c|}
\hline & & & Correlations & \\
\hline Control Variables & & & $\begin{array}{c}\text { LgBDNF_Transcri } \\
\text { pt1_Exp_New }\end{array}$ & $\begin{array}{r}\text { LgBDNF_- } \\
\text { pt4_Exp }\end{array}$ \\
\hline RNA RIN Value \& Age at death & LgBDNF_Transcript1_Exp_New & Correlation & 1.000 & \\
\hline & & Significance (2-tailed) & . & \\
\hline & & df & 0 & \\
\hline & LgBDNF_Transcript4_Exp_New & Correlation & .596 & \\
\hline & & Significance (2-tailed) & .000 & \\
\hline & & df & 47 & \\
\hline & LgBDNF_Total_Exp_New & Correlation & .301 & \\
\hline & & Significance (2-tailed) & .035 & \\
\hline & & df & 47 & \\
\hline & LgMeth_Proml_Avg & Correlation & -.253 & \\
\hline & & Significance (2-tailed) & .080 & \\
\hline & & df & 47 & \\
\hline & LgMeth_PromIV_Avg & Correlation & -.090 & \\
\hline & & Significance (2-tailed) & .539 & \\
\hline & & df & 47 & \\
\hline & LgBDNFprotein & Correlation & .266 & \\
\hline & & Significance (2-tailed) & .065 & \\
\hline & & df & 47 & \\
\hline
\end{tabular}

